\title{
Economics of Organic Farming over Conventional Farming- A Case Study in Karnataka, India
}

\author{
M. Mohan Kumar ${ }^{1}$, L. K. Adarsha ${ }^{2 *}$, Shyam Prakash Singh ${ }^{2}$ and K. Likin Boppana ${ }^{1}$ \\ ${ }^{1}$ (Ag) UAS Bangalore, Karnataka, India \\ ${ }^{2}$ Agricultural Economics BCKV, West Bengal, India \\ *Corresponding author
}

\author{
A B S T R A C T
}

\begin{tabular}{|l|}
\hline Ke y w o r d s \\
Organic farming, \\
Conventional farming, \\
B: C ratio. \\
\hline Article Info \\
\hline $\begin{array}{l}\text { Accepted: } \\
\text { 20 September } 2017 \\
\text { Available Online: } \\
\text { 10 November } 2017\end{array}$ \\
\hline
\end{tabular}

Organic farming has the potential to provide benefits in terms of environmental protection, conservation of non-renewable resources and improved food quality. India is bestowed with lot of potential to produce all varieties of organic products due to its diverse agroclimatic regions. In several parts of the country, the inherited tradition of organic farming is an added advantage. This holds promise for the organic producers to tap the market which is growing steadily in the domestic market related to the export market. Cost of production and benefit cost ration has been calculated for ragi and maize crops of both organic and conventional farming meanwhile comparison among them also carried out. It is found that cost of production of organic ragi and maize per acre were Rs.24817 and Rs.30299 which is more than conventional farming i.e., Rs.17128 and Rs. 21655 respectively. Whereas $\mathrm{B}$ : $\mathrm{C}$ ratio for organic ragi and maize found to be 1.08 and 1.37 which is higher than the conventional farming of 0.78 and 1.12 . Government needs to spread awareness about organic farming through proper policies.

\section{Introduction}

Increasing awareness towards health and environmental issues associated with the intensive use of chemical inputs has led to alternate forms of agriculture. Organic farming is one among the production methods that are supportive of the environment (Kavitha et al., 2013).

India's rank in terms of World's Organic Agricultural land was 15 as per 2013 data. The total area under organic certification is 5.71million Hectare (2015-16). This includes $26 \%$ cultivable area with 1.49 million Hectare and rest 74\% (4.22 million Hectare) forest and wild area for collection of minor forest produces (APEDA, 2015). Organic farming systems have attracted increasing attention over the last one decade because they are perceived to offer some solutions to the problems currently besetting the agricultural sector. Organic farming has the potential to provide benefits in terms of environmental protection, conservation of non-renewable resources and improved food quality (Worthington, 2001; Haas et al., 2005).

The study revealed that organic farming, in spite of the reduction in crop productivity by $9.2 \%$ provided higher net profits to farmers 
by $22.0 \%$ compared to conventional farming. This was mainly due to available of premium price (20-40\%) for the certified organic produce and reduction in cost of cultivation by $11.7 \%$. in cases, where such premium prices were not available and cost of cultivation was higher primarily due to purchased off-farm inputs. The most important constraints identified by the organic growers in productivity of organic turmeric and cotton were non availability of labor and organic certification whereas conventional growers' constraints were non availability of labor and high wage rate (Amarnath and Sridhar, 2012). However, benefits such as positive environmental and health effects of organic production are difficult to assess economically, and subsidies for conventional fertilizers and pesticides may be ignored.

Many times the question is raised why organic systems do not compare too well with chemically based systems. Lower and less stable yield levels, especially during the 2-5 year conversion period, are often criticized. Replying such queries requires good knowledge and experience, which is becoming rare since too little long-term research is carried out. (Ramesh et al., 2010)

Hence, Organic agriculture as an effective strategy to promote sustainable agriculture in India. A sustainable agricultural sector strategy can contribute to a broader development of agricultural productivity, food security, generation of rural employment and poverty reduction while promoting the conservation of the natural resource base. This new strategy should be adopted with sound infrastructure, governance, the private public participation and effective implementation seeking to contribute to poverty reduction, enhance regional integration, accelerate rural development and improve productivity in agriculture (Soumya, 2015).

\section{Materials and Methods}

\section{Data source}

The study is absolutely based on primary data source, related on various aspects of organic farming system is collected from sampled farmers who were practicing the organic ragi and maize farming since from 2007. Those details are used to calculate cost and returns of production. The information on quantities and prices of different inputs used in production and labor used was collected.

\section{Sampling design}

Simple random sampling procedure was followed. In the first stage in Karnataka, Chamarajanagar district was purposively selected, since in view of successful implementation of organic village program in the district.

In the next stage a cluster of four villages were selected deliberately, because more number of farmers practicing organic farming was observed in these villages on the one hand and on the other in these selected villages the organic village program was successfully implemented.

In the final stage, 45 farmers practicing organic farming and 45 farmers conventional farming were selected randomly.

\section{Cost of production}

The variable costs were the farm expenditure on seed, fertilizers, human labor, bullock labor, etc. Total cost of production was calculated by adding all the expenditure on variable inputs as below (Raj, 2011).

Total cost $=\sum$ of cost of all variable inputs. $=$ cost of land preparation + cost of fertilizer + cost of human labor + cost of other inputs 


\section{Benefit cost ratio analysis}

Benefit cost ratio is ratio between the gross return and total cost of any enterprise. In this study, benefit cost ratio was calculated by using the formula:

\section{B: C ratio $=\frac{\text { return }}{l \text { cost }}$}

\section{Results and Discussion}

The results have been arranged in the sequence of the objective of the study and summarized in the logical tabular form.

\section{Cropping pattern}

The cropping patterns of sample organic and conventional farmers are presented in Table 1 Farmers grow a number of crops on their farm. Ragi, Maize and Potato were the major crops grown in sample area the net cultivated area of the organic farmers in the sample villages was 58.48 ha where as it was 147.75 ha in case of conventional farmer The gross cropped area and cropping intensity was found to be 73.48 ha and 79.58 percent, respectively in organic farming where as in conventional farming it was 159.75 ha and 92.48 per cent, respectively.

Ragi, Maize and potato accounted for 21.20 per cent, 27.40 per cent and 30.89 per cent respectively in grossed cropped area of organic farms whereas these crops accounted for 19.56 per cent, 31.77 per cent and 34.91 per cent respectively in the gross cropped area of conventional farms.

Avare and vegetables were grown organically in rabi season accounting for 6.8 per cent and 13.61 per cent respectively, in case of conventional farms both the crops accounted for 2.82 per cent and 4.61 per cent respectively.

\section{Input utilization pattern}

The details of input utilization pattern by organic and conventional farmers is presented in Table 2 Farm yard manure and bio fertilizer were used by both the category of farmers, one hundred per cent of organic farmers and 86.66 per cent of conventional farmers used FYM, with regard to biofertilizers 86.66 per cent of organic and 53.33 per cent of conventional farmers used this on their farm. All other inputs like vermicompost, green manure, bio-pesticides, oil cakes and bio-digester liquids were used to the extent of 83.33 per cent, 66.66 per cent, 93 per cent, 50 per cent and 26.6 per cent, respectively in case of organic farms. The use of these inputs was negligible in case of conventional farms whereas all these farmers used fertilizers (100 per cent) and plant protection chemicals (100 per cent) instead of organic manures and bio-pesticides.

The quantity of inputs utilized per acre by organic and conventional farmers during the study period is presented in Table 3. Farm yard manure was used to the extent of 4.6 tons and 2.7 tons per acre per year respectively by organic and conventional farmer The inputs like vermicompost, green manure were used to the extent of 432.6 tons and 1.3 tons per acre respectively by organic farmers and whereas conventional farmers used 80.1 ton and 0.80 tons of vermicompost and green manure per acre per year respectively. Both the category of farmers used Bio-fertilizers to the extent of $1.20 \mathrm{Kgs}$ and $0.70 \mathrm{Kgs}$, respectively and bio-pesticides were used to an extent of 1.86 liters per acre by organic farmers and no conventional farmer was using bio-pesticide for pest control. Oil cakes (Neem cake) and bio digester liquid was used by both organic and conventional farmers, oilcakes and biodigester liquid accounted for $300.96 \mathrm{Kgs}$ and $45.78 \mathrm{Kgs}$ per acre and bio-digester liquids like Jeevamrutha usage accounted for 95.8 
liters and 22.14 liters respectively. Fertilizers were used to the extent of 2.26 quintals per acre and pesticides use was 0.74 liters by sample conventional farmer.

Table.1 Cropping pattern of Sample farmers in the study Area

\begin{tabular}{|c|c|c|c|c|c|c|}
\hline \multirow{2}{*}{ Sl. No. } & \multirow{2}{*}{ Season } & \multirow{2}{*}{ Crops } & \multicolumn{2}{|c|}{ Organic farmers } & \multicolumn{2}{|c|}{ Conventional Farmers } \\
\hline & & & Area in ha & Per cent & Area in ha & Per cent \\
\hline \multirow{5}{*}{1} & \multirow{5}{*}{ Kharif } & Maize & 15.58 & 21.20 & 50.75 & 31.77 \\
\hline & & Ragi & 20.2 & 27.49 & 31.25 & 19.56 \\
\hline & & Potato & 22.7 & 30.89 & 55.75 & 34.90 \\
\hline & & Beans & 0 & 0.00 & 10 & 6.26 \\
\hline & & Sub Total & 58.48 & 79.59 & 147.75 & 92.49 \\
\hline \multirow{3}{*}{2} & \multirow{2}{*}{ Rabi } & Avare & 5 & 6.80 & 4.5 & 2.82 \\
\hline & & Vegetables & 10 & 13.61 & 7.5 & 4.69 \\
\hline & & Sub Total & 15 & 20.41 & 12 & 7.51 \\
\hline 4 & \multicolumn{2}{|c|}{ Gross cropped area } & \multicolumn{2}{|c|}{73.48} & \multicolumn{2}{|c|}{159.75} \\
\hline 5 & \multicolumn{2}{|c|}{ Net cropped area } & \multicolumn{2}{|c|}{58.48} & \multicolumn{2}{|c|}{147.75} \\
\hline 6 & \multicolumn{2}{|c|}{ Cropping intensity } & \multicolumn{2}{|c|}{79.58} & \multicolumn{2}{|c|}{92.48} \\
\hline
\end{tabular}

Table.2 Distribution of farmers according to input use pattern

\begin{tabular}{|c|l|c|c|}
\hline Sl.No. & Type of Input & Organic & Conventional \\
\hline 1 & FYM & $45(100)$ & $38(86.66)$ \\
\hline 2 & Vermicompost & $37(83.33)$ & $12(26.6)$ \\
\hline 3 & Bio-pesticides & $42(93.33)$ & - \\
\hline 4 & Bio-fertilizers & $38(86.6)$ & $24(53.3)$ \\
\hline 5 & Bio-digester liquids & $12(26.6)$ & $4(10)$ \\
\hline 6 & Green manures & $30(66.6)$ & $11(30)$ \\
\hline 7 & Oil cakes & $23(50)$ & $8(16.6)$ \\
\hline 8 & Fertilizers & - & $45(100)$ \\
\hline 9 & PP Chemicals & - & $45(100)$ \\
\hline
\end{tabular}

Note: Figures in the parenthesis indicates percentages.

Table.3 Input use pattern in organic and conventional farms (per acre/year)

\begin{tabular}{|c|c|c|c|c|c|c|c|c|}
\hline \multirow[b]{2}{*}{ SI.No. } & \multirow[b]{2}{*}{ Inputs } & \multirow[b]{2}{*}{ Units } & \multicolumn{2}{|c|}{ Organic farms } & \multicolumn{2}{|c|}{ Conventional farms } & \multicolumn{2}{|c|}{ Difference } \\
\hline & & & $\begin{array}{l}\text { Qty } \\
\text { (Kg) }\end{array}$ & $\begin{array}{l}\text { Value } \\
\text { (Rs.) }\end{array}$ & $\begin{array}{l}\text { Qty } \\
(\mathbf{K g})\end{array}$ & $\begin{array}{l}\text { Value } \\
\text { (Rs.) }\end{array}$ & $\begin{array}{l}\text { Qty } \\
\text { (Kg) }\end{array}$ & $\begin{array}{l}\text { Value } \\
\text { (Rs.) }\end{array}$ \\
\hline 1 & FYM & Ton & 4.6 & 5888 & 2.7 & 3456 & 1.833 & 2346.66 \\
\hline 2 & Vermicompost & Ton & 432.6 & 432.6 & 80.01 & 80 & 352.8 & 352.9 \\
\hline 3 & Oil cakes & Kgs & 300.96 & 3050 & 45.78 & 480 & 255.18 & 2500 \\
\hline 4 & Green manures & Kgs & 1.3 & 346.8 & 0.801 & 226.3 & 0.499 & 119.7 \\
\hline 5 & Bio-pesticides & Ton & 1.86 & 128.3 & - & - & 1.86 & 128.3 \\
\hline 6 & $\begin{array}{l}\text { Bio-digester } \\
\text { liquids }\end{array}$ & Lit & 95.8 & 46.23 & 22.14 & 10.3 & 73.66 & 35.98 \\
\hline 7 & Bio-fertilizers & Lit & 1.20 & 96.89 & 0.70 & 56.7 & 0.50 & 40.19 \\
\hline 8 & Fertilizers & Kgs & - & & 2.26 & 1650 & -2.26 & -1650 \\
\hline 9 & PP chemicals & Qtls & - & - & 0.74 & 480 & -0.74 & -480 \\
\hline 10 & Total value & Lit & & 9988.82 & & 6439.3 & & 3549.52 \\
\hline
\end{tabular}


Table.4 Cost of cultivation of ragi (Per Acre)

\begin{tabular}{|c|c|c|c|c|c|c|c|}
\hline \multirow[b]{2}{*}{$\begin{array}{l}\text { Sl. } \\
\text { No. }\end{array}$} & \multirow[b]{2}{*}{ Particulars } & \multicolumn{3}{|c|}{ Organic } & \multicolumn{3}{|c|}{ Conventional } \\
\hline & & Qty & $\begin{array}{l}\text { Cost } \\
\text { (Rs.) }\end{array}$ & $\%$ & Qty. & $\begin{array}{l}\text { Cost } \\
\text { (Rs.) }\end{array}$ & $\%$ \\
\hline \multirow[t]{13}{*}{ I } & Variable cost & & & & & & \\
\hline & Human labour (Mandays) & 18 & 3678.23 & 14.82 & 15.00 & 3059.2 & 17.26 \\
\hline & Bullock labour (BP days) & 3 & 1547.52 & 6.23 & 2.00 & 856.78 & 4.83 \\
\hline & Machine labour (hours) & 4 & 1673.02 & 6.74 & 3.51 & 1580.6 & 8.92 \\
\hline & Seed $(\mathrm{kgs})$ & 7 & 263.30 & 1.06 & 6.32 & 101.12 & 0.57 \\
\hline & FYM (tonne) & 4 & 7277.00 & 29.32 & 2.99 & 3446.4 & 19.45 \\
\hline & Fertilizer (Kgs) & & - & - & 96.00 & 1294.4 & 7.30 \\
\hline & Urea (Kgs) & & - & - & 55.60 & 333.60 & 1.88 \\
\hline & $\mathrm{DAP}(\mathrm{Kgs})$ & & - & - & 40.00 & 960.21 & 5.42 \\
\hline & $\begin{array}{l}\text { Organic } \\
\text { manure \& Bio- fertilizer(Kgs) }\end{array}$ & & 86.39 & 3.97 & & & - \\
\hline & $\begin{array}{l}\text { Managerial cost @ 10 } \\
\text { percent of variable cost }\end{array}$ & & 665.93 & 6.71 & & 6.45 & - \\
\hline & $\begin{array}{l}\text { Interest on working capital @ 8 per } \\
\text { cent }\end{array}$ & & 234.02 & 4.97 & & 7.66 & 4.67 \\
\hline & Total variable cost & & 324.90 & 73.84 & & 280 & 69.30 \\
\hline \multirow[t]{7}{*}{ II } & Fixed cost & & & & & & \\
\hline & Depreciation & & 03.48 & 6.06 & & 0.80 & 6.10 \\
\hline & Land revenue & & 5.00 & 0.02 & & 00 & 0.03 \\
\hline & Interest on fixed capital @ 10 per cent & & 50.85 & 0.61 & & 9.21 & 0.61 \\
\hline & Rental value of land & & 00.00 & 12.09 & & 0.07 & 16.93 \\
\hline & $\begin{array}{l}\text { Risk premium @ } 10 \% \text { of variable } \\
\text { cost }\end{array}$ & & 32.49 & 7.38 & & 8.04 & 6.37 \\
\hline & Total fixed cost & & 92.87 & 26.16 & & 2.45 & 30.04 \\
\hline III & Total cost of cultivation & & 4817 & 100 & & 719 & $\begin{array}{c}100.0 \\
0\end{array}$ \\
\hline
\end{tabular}

Table.5 Returns from ragi cultivation (Per Acre)

\begin{tabular}{|c|l|r|r|r|r|}
\hline Sl. No. & \multicolumn{1}{|c|}{ Particulars } & \multicolumn{2}{c|}{ Organic } & \multicolumn{2}{c|}{ Conventional } \\
\hline I & Returns & Quantity & $\begin{array}{c}\text { Value in } \\
\text { Rs. }\end{array}$ & \multirow{2}{*}{ Quantity } & $\begin{array}{c}\text { Value in } \\
\text { Rs. }\end{array}$ \\
\hline & Main product (Qtl.) & 7.45 & 26076.73 & 7.48 & 12729.60 \\
\hline & By product (Tl) & 10.64 & 2128.71 & 9.66 & 2416.00 \\
\hline & Gross returns (Rs.) & & 28205.45 & & 15145.60 \\
\hline & Net returns (Rs.) & & 3388.73 & & -2573.62 \\
\hline & Cost of production (Rs./Qtl.) & & 3330.88 & & 2366.35 \\
\hline & Price (Rs./quintal)* & & 3500 & & 1700 \\
\hline II & B:C ratio & & 1.08 & & 0.72 \\
\hline
\end{tabular}

Note: * Price Paid by the Sahaja samrudhi (NGO) which is buying organic produce from the sample farmer. 
Table.6 Cost of cultivation of maize (Per Acre)

\begin{tabular}{|c|c|c|c|c|c|c|c|}
\hline \multirow[b]{2}{*}{$\begin{array}{l}\text { Sl. } \\
\text { No. }\end{array}$} & \multirow[b]{2}{*}{ Particulars } & \multicolumn{3}{|c|}{ Organic } & \multicolumn{3}{|c|}{ Conventional } \\
\hline & & Qty. & $\begin{array}{l}\text { Cost } \\
\text { (Rs.) }\end{array}$ & $\%$ & Qty. & $\begin{array}{l}\text { Cost } \\
\text { (Rs.) }\end{array}$ & $\%$ \\
\hline \multirow[t]{15}{*}{$\mathbf{I}$} & Variable cost & & & & & & \\
\hline & Human labour (Mandays) & 31 & 6266.72 & 20.68 & 24.2 & 4848.43 & 21.00 \\
\hline & Bullock labour (BP days) & 4 & 2151.53 & 7.10 & 1.7 & 848.45 & 3.68 \\
\hline & Machine labour (hours) & 3.9 & 1574.31 & 5.20 & 3.0 & 1673.16 & 7.25 \\
\hline & Seed (kgs) & 9.3 & 251.56 & 0.83 & 8.3 & 829.81 & 3.59 \\
\hline & FYM (tonne) & 3.8 & 5818.21 & 19.20 & 1.4 & 2123.70 & 9.20 \\
\hline & Organic manure \& Bio-Fertilizer(Kgs) & & 1684.50 & 5.56 & - & - & - \\
\hline & PP Chemical cost & & - & - & - & - & - \\
\hline & Fertilizer cost & & - & - & 131 & 1459.57 & 6.32 \\
\hline & Urea(Kgs) & & - & - & 83 & 499.50 & - \\
\hline & DAP(Kgs) & & - & - & 48 & 1160.91 & - \\
\hline & Threshing and winnowing cost & & 570.23 & 5.18 & \multicolumn{2}{|c|}{1431.14} & 6.20 \\
\hline & $\begin{array}{l}\text { Managerial cost @ 10\% of } \\
\text { variable cost }\end{array}$ & & 080.62 & 6.87 & \multicolumn{2}{|c|}{1427.12} & 6.18 \\
\hline & $\begin{array}{l}\text { Interest on working capital @ } \\
8 \text { per cent }\end{array}$ & & 541.21 & 5.09 & \multicolumn{2}{|c|}{1057.15} & 4.58 \\
\hline & Total variable cost & & 886.35 & 75.53 & \multicolumn{2}{|c|}{15698.17} & 68.01 \\
\hline \multirow[t]{7}{*}{ II } & Fixed cost & & & & & & \\
\hline & Depreciation & & 926.81 & 6.36 & \multicolumn{2}{|c|}{1256.94} & 5.44 \\
\hline & Land revenue & & 5.00 & 0.02 & \multicolumn{2}{|c|}{5.00} & 0.0217 \\
\hline & $\begin{array}{l}\text { Risk premium @ } 10 \% \text { of } \\
\text { variable cost }\end{array}$ & & 288.63 & 7.55 & \multicolumn{2}{|c|}{1569.81} & 6.8007 \\
\hline & $\begin{array}{l}\text { Interest on fixed capital @ } 10 \\
\text { per cent }\end{array}$ & & 93.22 & 0.64 & \multicolumn{2}{|c|}{126.21} & 0.55 \\
\hline & Rental value of land & & 000.00 & 9.90 & \multicolumn{2}{|c|}{3000.00} & 13.00 \\
\hline & Total fixed cost & & 413.61 & 24.47 & \multicolumn{2}{|c|}{5956.94} & 31.99 \\
\hline III & Total cost of cultivation & & 299.91 & 100.00 & \multicolumn{2}{|c|}{21655} & 100.00 \\
\hline
\end{tabular}

Table.7 Returns from maize cultivation (Per Acre)

\begin{tabular}{|c|l|r|r|r|r|}
\hline $\begin{array}{l}\text { Sl. } \\
\text { No. }\end{array}$ & \multicolumn{1}{|c|}{ Particulars } & \multicolumn{2}{c|}{ Organic } & \multicolumn{2}{c|}{ Conventional } \\
\hline I & Returns & Quantity & $\begin{array}{c}\text { Value in } \\
\text { Rs. }\end{array}$ & Quantity & Value in Rs. \\
\hline & Main product (Qtl) & 19.8 & 39636.36 & 22.1 & 25824.19 \\
\hline & By product (Tl) & 1.0 & 1003.03 & 1.0 & 1041.86 \\
\hline & By product (No.Bags) & 29.8 & 803.45 & 30.8 & 831.85 \\
\hline & Gross returns (Rs.) & & 41436.79 & & 27697.90 \\
\hline & Net returns (Rs.) & & 11136.88 & & 4614.81 \\
\hline & Cost of production (Rs../Qtl) & & 1528.89 & & 1042.62 \\
\hline & Price per quintal of maize (Rs./Qtl) & & 2100 & & 1200 \\
\hline II & B:C ratio & & 1.37 & & 1.12 \\
\hline
\end{tabular}

Note: * Price Paid by the Sahaja samrudhi (NGO) which is buying organic produce from the sample farmer 


\section{Cost and returns structure}

\section{Cost of cultivation of ragi}

The detail of cost per acre of ragi cultivation under both organic and conventional farming situations are presented in Table 4. The results indicated that, the total cost of cultivation of ragi per acre was Rs. 24817 and Rs. 17719 under organic and conventional farming, respectively. The total variable cost was Rs. 18324 and Rs. 12280 under organic and conventional ragi cultivation accounted for 73.84 and 69.30 per cent to the total cost respectively. The fixed cost was Rs. 6492 and Rs. 5322 accounting for 26.16 and 30.04 per cent to total cost respectively for organic and conventional farms. The analysis of operational cost incurred in ragi production revealed that, FYM accounted for major portion $(29.32 \%)$ of the total cost followed by Labor cost $(27.79 \%)$ under organic farms and in conventional ragi cultivation. Major cost incurred out of total cost was $19.45 \%$, $31.01 \%$ and $7.36 \%$ for FYM, labor and fertilizers respectively.

\section{Returns from ragi cultivation}

The detail of returns per quintal of ragi production is presented in table 5 . Net returns realized from organically produced ragi was Rs. 3088.73. The net returns realized (Rs. 2572.3) were negative under conventional farming. B: C ratio were 1.08 and 0.72 for ragi production under organic and conventional farming, which imply organic farming not only profitable but also economically viable compared to conventional ragi production.

\section{Cost of cultivation of maize}

The details of per acre cost of maize cultivation under both farm situations are presented in Table 6 . The results indicated that, the total cost of cultivation of maize per acre was Rs. 30299 and Rs. 23083 under organic and conventional farming, respectively. The total variable cost was Rs. 22886.3 and Rs. 15698 under organic and conventional maize cultivation accounted for 75.53 and 68.01 per cent to the total cost respectively. The fixed cost was Rs. 7412 and Rs. 7385 accounting for 24.47 and 31.99 per cent to total cost respectively for organic and conventional farms. The analysis of operational cost incurred in maize production revealed that, Labor accounted for major portion $(32.98 \%)$ of the total cost followed by the expenditure on FYM (19.20\%) respectively under organic and conventional maize production. Cost of fertilizer accounted for 6.32 per cent of the total cost in the case of conventional farmer.

\section{Returns from maize cultivation}

The detail of returns per quintal of maize production is presented in table 7 . Then a net return from organic and conventional maize production was Rs. 41436.79 and Rs. 27697.90. B: C ratio were Rs. 1.37 and Rs. 1.12 under organic and conventional maize farming, which implies not only profitable but also economic viability of both the farming systems.

The organic farming has emerged as an alternative system of farming which not only address the quality and sustainability concerns, but also ensure profitable livelihood option for rural community. Due to very little accessible information on economics and efficiency of organic farming, an attempt is made to assess it in different crops. The crop economics results showed a positive result on organic farming. In general, organic farming is a production system which has low productivity levels, needs more labor, require low energy inputs and has a changing net income levels along with selling prices. 
Overall, crop economics results concluded that the $\mathrm{B}$ : $\mathrm{C}$ ratio of ragi is 1.08 in case of organic farming which is more than the conventional farming of 0.72 . Likewise, in case of maize $\mathrm{B}: \mathrm{C}$ ratio is 1.37 in organic farming which is a little bit higher than that of conventional farming of $\mathrm{B}: \mathrm{C}$ ratio 1.12 . Hence, we can conclude that organic farming is more profitable than the conventional farming as well as organic farming keeps environment good. The major problem we found that farmers have to give their valuable time for conversion of conventional farming land to organic farming land. Government needs to spread awareness among farmers about nature damage by chemical usage and should promote organic farming by making proper policies.

\section{References}

Amarnath, J. S and Sridhar, V (2012), An Economic Analysis Of Organic Farming In Tamil Nadu, India, Bangladesh Journal of Agricultural Economics. XXXV, 1\&2 33-51.

APEDA (2015) http://apeda.gov.in/ apedawebsite/organic/Organic_Products .htm.

Hass, G, Geier U, Frieben B and Kopke U 2005 Estimation of environmental impact of conversion to organic agriculture in Hamburg using the LifeCycle-Assessment method, Organic Agro-expertise Consultancy (www.agroexpertise.de), Germany

Kavitha, V., Chandran, K and Kavitha, B. (2013) Economic analysis of organic and $\mathrm{Bt}$ farming of cotton in Erode District Of Tamil Nadu. Global Journal of bioscience and biotechnology vol.2 (3) $313-316$

Raj, K. Adhikari (2011), Economics of organic rice production. The Journal of Agriculture and Environment Vol.12

Ramesh, P., Panwar, N. R., Singh, A. B., Ramana, S., Yadav, S. K., Shrivastava, $\mathrm{R}$ andSubba Rao, A., (2010): Status of organic farming in India. Current. Science. 98, pp. 1090-1194.

Soumya,. K.M., (2015) Organic Farming: An Effective Way to Promote Sustainable Agriculture Development in India. IOSR Journal of Humanities And Social Science Vol 20, Issue 6, PP 31-36.

Worthington, V., (2001) Nutritional quality of organic versus conventional fruits, vegetables and grains. The Journal of Alternative and Complementary Medicine 7(2): 161-173

\section{How to cite this article:}

Mohan Kumar, M., L.K. Adarsha, Shyam Prakash Singh and Likin Boppana, K. 2017. Economics of Organic Farming over Conventional Farming-A Case Study in Karnataka. Int.J.Curr.Microbiol.App.Sci. 6(11): 2810-2817. doi: https://doi.org/10.20546/ijcmas.2017.611.331 